\title{
Cu-MCM-41 nanoparticles: An efficient catalyst for the synthesis of 5-substituted $1 H$-tetrazoles via [3+2] cycloaddition reaction of nitriles and sodium azide
}

\author{
MOHAMMAD ABDOLLAHI-ALIBEIK* and ALI MOADDELI \\ Department of Chemistry, Yazd University, Yazd 89158-13149, Iran \\ e-mail: abdollahi@yazd.ac.ir; moabdollahi@gmail.com
}

MS received 12 August 2015; revised 20 October 2015; accepted 9 November 2015

\begin{abstract}
NaN}_{3}\right)$ were studied in the presence of nano-sized $\mathrm{Cu}-\mathrm{MCM}-41$ as an efficient recoverable heterogeneous catalyst. Nano-sized CuMCM-41 mesoporous molecular sieves with various $\mathrm{Si} / \mathrm{Cu}$ molar ratios were synthesized by direct insertion of metal ions at room temperature. The textural properties of the materials have been studied by means of XRD, FTIR, SEM and TEM techniques. Catalytic behavior of Cu-MCM-41 was also investigated by pyridine absorption and potentiometric titration. The reactions data verified characterization results and show that $\mathrm{Cu}-$ MCM-41 with Si/Cu molar ratio of 20 has considerably better catalytic activity compared to the other molar ratios. To investigate reusability, the catalyst was recovered by simple filtration and reused for several cycles with consistent activity.
\end{abstract}

Keywords. 5-substituted $1 \mathrm{H}$-tetrazoles; heterogeneous catalyst; Cu-MCM-41; nanoparticles; cyclization.

\section{Introduction}

Tetrazoles as a class of heterocycles are currently under intensive focus because of broad spectrum of applications in pharmaceuticals as lipophilic spacers, carboxylic acid surrogates, ${ }^{1}$ speciality explosives ${ }^{2}$ photography and information recording systems. ${ }^{3}$ Tetrazoles are almost 10 times more lipophilic than the corresponding carboxylates, which is an important factor to bear in mind when designing a drug molecule to pass through cell membranes. Another advantage of tetrazolic acids over carboxylic acids is that they are resistant to many biological metabolic degradation pathways. ${ }^{3}$

Conventionally 5 -substituted $1 H$-tetrazoles are synthesized via reaction of nitriles with hydrazoic acid, ${ }^{4}$ Sodium azide ${ }^{5,6}$ and trimethylsilylazide $\left(\mathrm{TMSN}_{3}\right){ }^{7}$ Among them, general method is [3+2] cycloaddition of sodium azide with various nitriles. Various catalytic systems have been introduced for this type of reaction for manipulation of this reaction through the past few years such as Brønsted acids, ${ }^{8}$ Lewis acids including $\mathrm{BF}_{3} . \mathrm{OEt}_{2},{ }^{9}$ $\mathrm{AlCl}_{3},{ }^{10}$ metal oxides such as $\mathrm{Cu}_{2} \mathrm{O},{ }^{11} \mathrm{ZnO},{ }^{12}$ clays and modified clays, ${ }^{13}$ etc. Nevertheless, existing protocols have some limitations such as stringent conditions, longer reaction times, expensive and toxic metal catalysts, tedious work-ups and impossible or unsatisfactory

*For correspondence recovery of the catalyst. To overcome the drawbacks of the earlier methods, attention has been paid to develop safer and neat methods for the synthesis of 5-substituted $1 H$-tetrazoles.

In recent years, tendency towards heterogeneous catalysts have received much attention because of recyclable and environmentally benign conditions. Ordered mesoporous materials such as mesoporous silica with narrow pore size distributions, high surface area and controllable morphologies are interesting for a wide range of applications in particular as heterogeneous catalysis or catalyst support. ${ }^{14,15}$ However, due to the low catalytic activity of MCM-41 as pure form, modified mesoporous materials based MCM-41 containing various transition metals such as $\mathrm{V},{ }^{16} \mathrm{Fe},{ }^{17} \mathrm{Cu},{ }^{18} \mathrm{Mn},{ }^{19}$ $\mathrm{Co},{ }^{20} \mathrm{Ni},{ }^{21}$ and $\mathrm{Mo}^{22}$ have emerged as useful heterogeneous catalysts.

Copper is an efficient, cheap and non-toxic ingredient in many heterogeneous and homogeneous catalysts, in particular in the synthesis of tetrazoles. ${ }^{23}$ In addition to this, copper-modified mesoporous silica show favorable activity and recoverability in the catalyzed transformations. ${ }^{24,25}$

We report herein, a new method for the preparation of nano-sized $\mathrm{Cu}-\mathrm{MCM}-41$ with different $\mathrm{Si} / \mathrm{Cu}$ molar ratios through direct insertion of copper ion in solgel step at room temperature without using autoclave. We hope that copper modified MCM-41 nanoparticles 


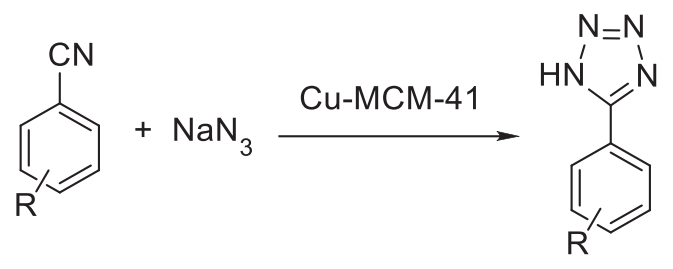

Scheme 1. Synthesis of 5-shubstituted $1 H$-tetrazoles using Cu-MCM-41.

efficiently catalyze the reaction of nitriles and sodium azide for the synthesis of 5 -substituted $1 \mathrm{H}$-tetrazoles (scheme 1).

\section{Experimental}

All chemicals were commercial products and used without further purification. All reactions were monitored by TLC and all yields refer to isolated products. Melting points were obtained by Buchi B-540 apparatus and are uncorrected. ${ }^{1} \mathrm{H}$ and ${ }^{13} \mathrm{C}$ NMR spectra were recorded in DMSO- $d_{6}$ on a Bruker DRX-400 AVANCE (400 MHz for ${ }^{1} \mathrm{H}$ and $100 \mathrm{MHz}$ for ${ }^{13} \mathrm{C}$ ) spectrometer. Infrared spectra of the catalysts and reaction products were recorded on a Bruker FT-IR Equinox 55 spectrophotometer in $\mathrm{KBr}$ disks. XRD patterns were recorded on a Bruker D8 ADVANCE X-ray diffractometer using nickel filtered $\mathrm{Cu} \mathrm{K} \alpha$ radiation $(\lambda=1.5406 \AA)$. Scanning Electron Microscopy (SEM) was performed using KYKY-EM3200 Instrument. Potentiometric data was collected using $\mathrm{pH} / \mathrm{mV}$ meter, AZ model 86502-pH/ ORP. Atomic absorption spectroscopy analysis was performed by analytic jena nova 300 model 330 Germany. Transmittance electron microscopy was performed with Zeiss-EM10C at $80 \mathrm{KV}$

\subsection{Catalyst preparation}

The synthesis of nano-sized $\mathrm{Cu}-\mathrm{MCM}-41$ was carried out by the method of direct insertion of copper ion in sol-gel preparation step at room temperature using tetraethyl orthosilicate (TEOS) as the $\mathrm{Si}$ source, cetyltrimethylammonium bromide $(\mathrm{CTAB})$ as the template, ammonia as the $\mathrm{pH}$ control agent and $\mathrm{Cu}(\mathrm{OAc})_{2} \cdot \mathrm{H}_{2} \mathrm{O}$ as the copper source with the gel composition of $\mathrm{SiO}_{2}$ : $\mathrm{Cu}(\mathrm{OAc})_{2} \cdot \mathrm{H}_{2} \mathrm{O}: \mathrm{CTAB}: \mathrm{NH}_{4} \mathrm{OH}: \mathrm{H}_{2} \mathrm{O}=1.00: 0.050: 0.127$ : 0.623:508 for typical preparation of Cu-MCM-41 with $\mathrm{Si}: \mathrm{Cu}$ molar ratio of 20. In a typical procedure, CTAB $(1.04 \mathrm{~g})$ was dissolved in deionized water $(200 \mathrm{~mL})$ under stirring, and then temperature was adjusted to $60^{\circ} \mathrm{C}$ for $15 \mathrm{~min}$. To this solution, tetraethylorthosilicate $(5 \mathrm{~mL})$ was added dropwise and then a solution of $\mathrm{Cu}$ $(\mathrm{OAc})_{2} \cdot \mathrm{H}_{2} \mathrm{O}$ (appropriate amount of copper precursor in $5 \mathrm{~mL}$ of deionized water) was added dropwise under vigorous stirring. Then $\mathrm{pH}$ of the solution was adjusted to 10.5 by adding $25 \mathrm{wt} \%$ ammonia solution. The mixture was stirred for $12 \mathrm{~h}$ at r.t. The gel was recovered by centrifuging and washed with ethanol $(3 \times 5 \mathrm{~mL})$ and deionized water $(3 \times 10 \mathrm{~mL})$. The obtained solid was dried at $120^{\circ} \mathrm{C}$ for $2 \mathrm{~h}$ and calcined in air at $550^{\circ} \mathrm{C}$ for $4 \mathrm{~h}$. The obtained samples with $\mathrm{Si} / \mathrm{Cu}$ molar ratio of 10 , 20 and 30 were denoted as 10-CM, 20-CM and 30-CM, respectively. The $\mathrm{Cu}$ content of the prepared catalysts was measured by AAS. Cu-MCM-41 samples with $\mathrm{Si} / \mathrm{Cu}$ molar ratio of 10,20 and 30 show $\mathrm{CuO} / \mathrm{SiO} 2$ molar ratios of the 10.8, 21.7 and 33.0, respectively. This showed that 7 to 9 percentage of copper ions was unreacted.

\subsection{General procedure for the synthesis of 5-substituted 1H-tetrazoles}

A mixture of nitrile ( $1 \mathrm{mmol})$, sodium azide $(1.5 \mathrm{mmol})$, catalyst ( $25 \mathrm{mg})$, and DMF ( $3 \mathrm{~mL}$ ) was taken in a $5 \mathrm{~mL}$ round bottomed flask and heated at $120^{\circ} \mathrm{C}$. After completion of the reaction (observed on TLC) the reaction mixture was cooled to r.t. and separated from catalyst by centrifugation. The solvent was removed under reduced pressure. The residue was dissolved in water $(5 \mathrm{~mL})$ and acidified with $\mathrm{HCl}(37 \%)$. The precipitation was filtered and crystallized in a mixture of water and ethanol. Further purification with column chromatography was not necessary.

\subsection{Physical and spectroscopic data for selected compounds}

2.3a 2-(1H-Tetrazole-5-yl)pyridine (2j): White solid; M.p.: $212-214^{\circ} \mathrm{C} ;{ }^{1} \mathrm{H}$ NMR (DMSO- $d_{6}, 400 \mathrm{MHz}$ ): $\delta$ $(\mathrm{ppm})=7.4(\mathrm{t}, J=6.4 \mathrm{~Hz}, 1 \mathrm{H}), 7.8(\mathrm{t}, J=6.4 \mathrm{~Hz}$, $1 \mathrm{H}), 8.0(\mathrm{t}, J=8.0 \mathrm{~Hz}, 1 \mathrm{H}), 8.5(\mathrm{~d}, J=3.2 \mathrm{~Hz}$, 1H) ppm; ${ }^{13} \mathrm{C}$ NMR (DMSO- $\left.d_{6}, 100 \mathrm{MHz}\right): \delta(\mathrm{ppm})$ $=167.5,159.1,150.0,139.4,120.2 \mathrm{ppm}$; IR $(\mathrm{KBr}) v$ : $3278,3181,2929,1662,1578,1390,923 \mathrm{~cm}^{-1}$.

2.3b 5-(4-Chlorophenyl)-1H-tetrazole (2c): White solid; M.p.: $252-253^{\circ} \mathrm{C} ;{ }^{1} \mathrm{H}$ NMR (acetone- $d_{6}, 400 \mathrm{MHz}$ ): $\delta$ $(\mathrm{ppm})=7.65(\mathrm{~d}, J=8.4 \mathrm{~Hz}, 2 \mathrm{H}), 8.15(\mathrm{~d}, J=8.4$ $\mathrm{Hz}, 2 \mathrm{H}$ ); ${ }^{13} \mathrm{C}$ NMR (acetone- $d_{6}, 100 \mathrm{MHz}$ ): $\delta$ (ppm) $=136.5,129.5,129.2,128.7,124.0 \mathrm{ppm} ; \mathrm{IR}(\mathrm{KBr}) v$ : 3060, 2460, 1900, 1608, 1486, 1435, $1100 \mathrm{~cm}^{-1}$.

2.3c 5-(thiophen-2-yl)-1H-tetrazole (2i): White solid; M.p.: $205-206^{\circ} \mathrm{C} ;{ }^{1} \mathrm{H}$ NMR (DMSO- $d_{6}, 400 \mathrm{MHz}$ ): $\delta$ $(\mathrm{ppm})=7.87(\mathrm{~m}, 1 \mathrm{H}), 7.79(\mathrm{~m}, 1 \mathrm{H}), 7.28(\mathrm{~m}, 1 \mathrm{H}) ;{ }^{13} \mathrm{C}$ 
NMR (DMSO- $\left.d_{6}, 100 \mathrm{MHz}\right): \delta(\mathrm{ppm})=151.3,130.4$, 129.2, 128.6, 125.4; ; IR (KBr) v: 3551, 3478, 3414, $3174,3110,3094,2891,2840,2502,1638,1593,1507$, $1414,1048,970,744,721 \mathrm{~cm}^{-1}$.

\section{Results and Discussion}

In this research, a new catalyst was developed for the synthesis of 5-substituted $1 H$-tetrazoles by reaction of various types of nitriles and sodium azide in the presence of $\mathrm{Cu}-\mathrm{MCM}-41$ as reusable solid acid catalyst. $\mathrm{Cu}$ MCM-41 with $\mathrm{Si} / \mathrm{Cu}$ molar ratio of 10,20 and 30 were prepared and denoted as 10-CM, 20-CM and 30-CM, respectively.

We have first characterized the prepared catalysts by various techniques before reaction optimization. The FT-IR absorption spectra of pure MCM-41 and $\mathrm{Cu}-$ incorporated MCM-41 samples with different loading amounts of copper are shown in figure 1. Cu-MCM41 samples show MCM-41 characteristic peaks but a slight red-shift of the vibration absorption band to the lower frequencies, corresponding to $v(\mathrm{Si}-\mathrm{O}-\mathrm{Si})$ at $\sim 1090 \mathrm{~cm}^{-1}$ and $v(\mathrm{Si}-\mathrm{OH})$ at $\sim 980 \mathrm{~cm}^{-1}$, was observed in the spectra of $\mathrm{Cu}-\mathrm{MCM}-41$ samples respect to the pure MCM-41. These results indicate the formation of $\mathrm{Si}-\mathrm{O}-\mathrm{Cu}$ bond and incorporation of $\mathrm{Cu}$ in the framework of MCM-41.

The low angle XRD patterns of $\mathrm{Cu}-\mathrm{MCM}-41$ samples with $\mathrm{Si} / \mathrm{Cu}$ molar ratio of 10,20 and 30 are shown in figure 2. The intensity of the main peak of $\mathrm{Cu}-\mathrm{MCM}-41$ samples decreased and the width of the peak increased with increase in copper content of the catalysts. These

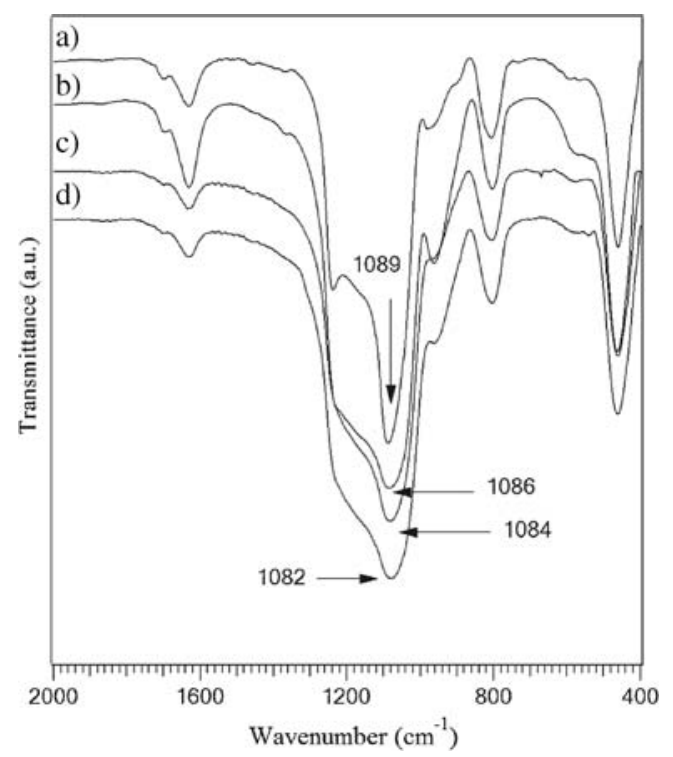

Figure 1. FT-IR spectra of (a) MCM-41, (b) 10-CM and (c) 20-CM and (d) 30-CM.

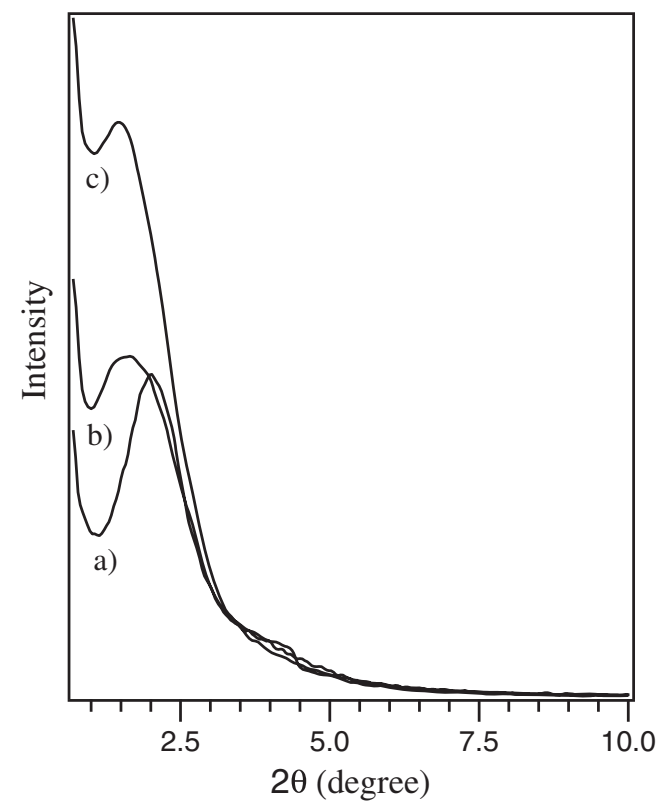

Figure 2. Low angle XRD patterns of (a) 10-CM, (b) 20$\mathrm{CM}$ and (c) 30-CM.

changes are due to decrease in the long-range order of the hexagonal meso-structure of MCM-41 due to the incorporation of copper into the framework of MCM41 and partial substitution of the structural $\mathrm{Si}^{4+}$ by the $\mathrm{Cu}^{2+}$ ion, resulting in the collapsing of the hexagonal structure of MCM-41.

As shown in figure $3 \mathrm{a}$, high angle XRD pattern of 10-CM shows slight presence of $\mathrm{CuO}$ in tenorite phase while 20-CM (figure $3 b$ ) lacks this phase. This fact shows high dispersion of copper ions in the MCM-41 framework and confirms the absence of segregate phase for $\mathrm{CuO}$ especially for 20-CM.

The morphology of $\mathrm{Cu}-\mathrm{MCM}-41$ particles was found spherical and nanoparticles had sizes of $<100 \mathrm{~nm}$ by using images from scanning electron microscopy (figure 4).

In order to obtain a clear distinction between Lewis and Brønsted acid sites, FT-IR analyses of pyridine adsorbed on the catalyst surface were carried out and re-

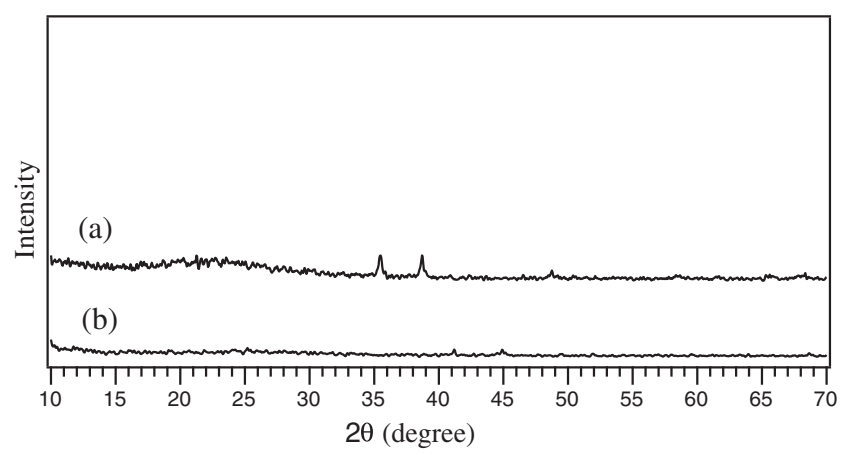

Figure 3. High angle XRD patterns of, (a) 10-CM, (b) 20-CM. 


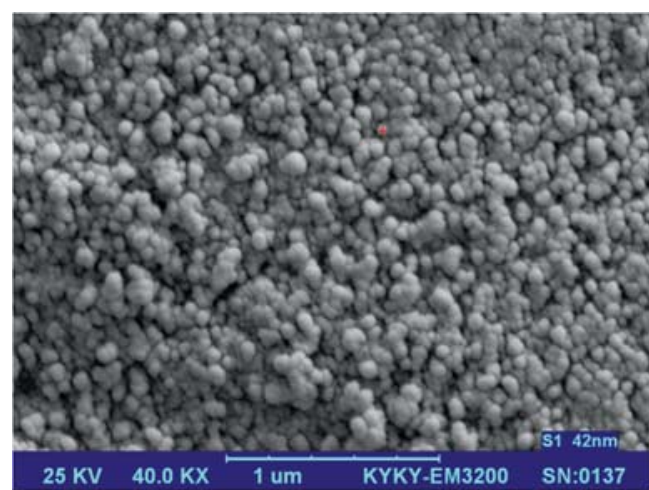

Figure 4. SEM image of 20-CM.

sults are displayed in figure 5. The FT-IR spectrum of pyridine adsorbed 20-CM before heat treatment (figure 5b) shows the contribution of pyridine adducts in the region of $1400-1650 \mathrm{~cm}^{-1}$. In this spectrum, the peaks at 1448 and $1598 \mathrm{~cm}^{-1}$ are attributed to pyridine bonded Lewis acid sites of the 20-CM. The weak peak at $1543 \mathrm{~cm}^{-1}$ assigned to Brønsted acid sites (corresponds to protonation of pyridine on Brønsted acid sites) is so hard to find in current zoom. The weak peak at $1491 \mathrm{~cm}^{-1}$ is attributed to the combination mode. As shown in figures $5 \mathrm{c}-\mathrm{g}$, with increasing in temperature, characteristic peaks of Lewis acidity still remained at

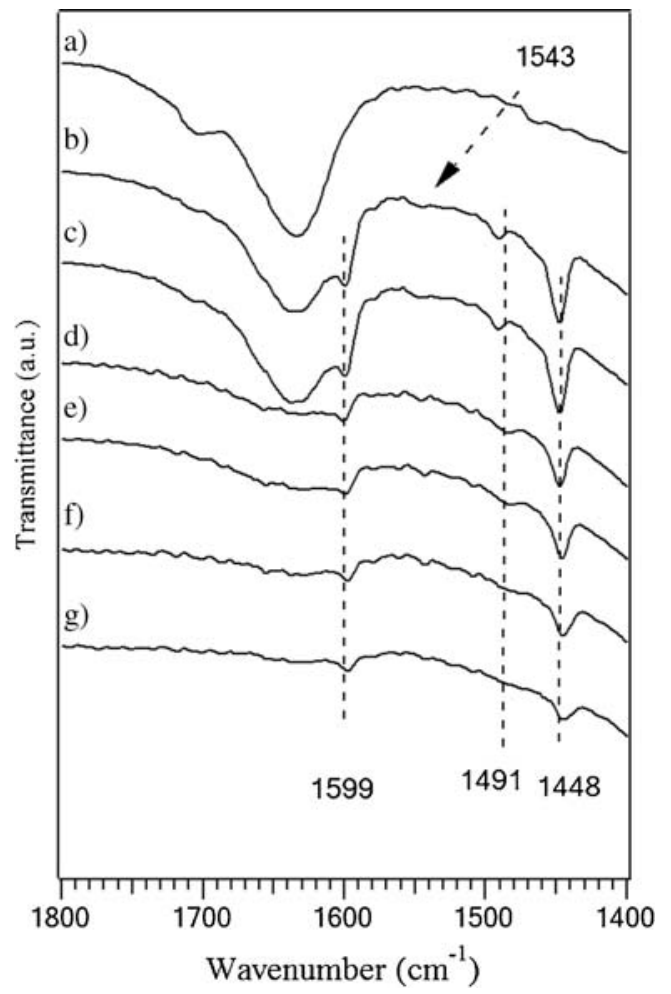

Figure 5. FT-IR spectra of (a) 20-CM, (b) pyridine adsorbed $20-\mathrm{CM}$ at ambient temperature, and pyridine adsorbed 20-CM heated at (c) $100^{\circ} \mathrm{C}$, (d) $200^{\circ} \mathrm{C}$, (e) $300^{\circ} \mathrm{C}$, (f) $400^{\circ} \mathrm{C}$ and $(\mathrm{g}) 500^{\circ} \mathrm{C}$.
1448 and $1599 \mathrm{~cm}^{-1}$. These results show that Lewis acidity character of the catalyst is stronger than its Brønsted acidity. ${ }^{26}$

The catalyst acidity character, including the acidic strength and the total number of acidic sites were determined by potentiometric titration. According to this method, the initial electrode potential $\left(\mathrm{E}_{\mathrm{i}}\right)$ indicates the maximum acid strength of the surface sites. ${ }^{27}$ Therefore, a suspension of the catalyst in acetonitrile was potentiometrically titrated with a solution of $0.02 \mathrm{M}$

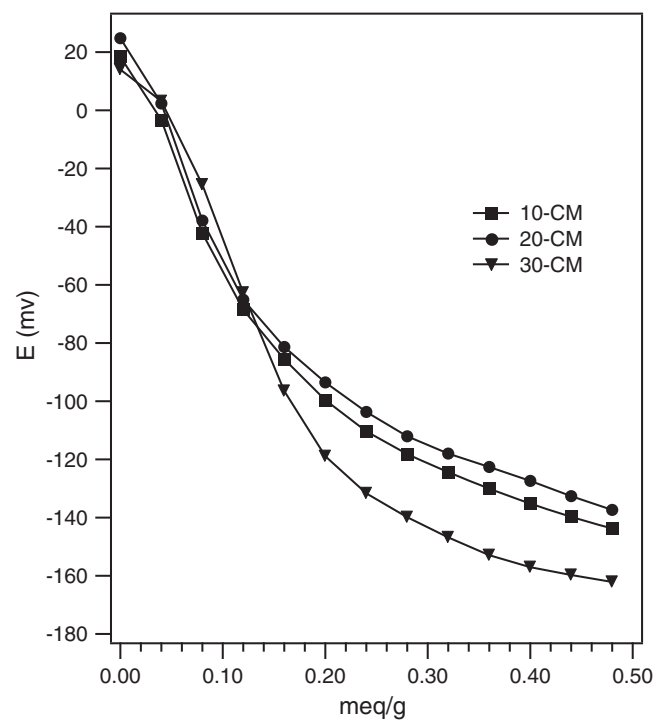

Figure 6. Potentiometric titration of (ロ) 10-CM, (•) 20$\mathrm{CM}$ and ( $\mathbf{\nabla}$ ) 30-CM. Titrant is a a solution of $0.02 \mathrm{M}$ $n$-butylamine in acetonitrile.

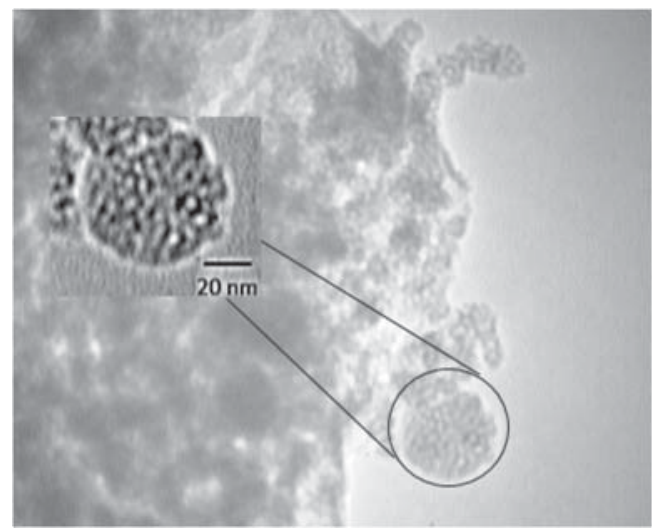

Figure 7. TEM image of 20-CM.<smiles>N#Cc1ccccc1</smiles>

Scheme 2. Model reaction for optimization of reaction conditions. 
Table 1. Screening of reaction parameters for the synthesis of phenyltetrazole ${ }^{a}$.

\begin{tabular}{lccccccc}
\hline Entry & $\begin{array}{c}\text { Si/Cu molar } \\
\text { ratio }\end{array}$ & $\begin{array}{c}\text { Temp. } \\
\left({ }^{\circ} \mathrm{C}\right)\end{array}$ & $\begin{array}{c}\text { Cat. amount } \\
(\mathrm{mg})\end{array}$ & $\begin{array}{c}\text { Cu content } \\
(\mathrm{mol} \%)^{\mathrm{b}}\end{array}$ & Solvent & $\begin{array}{c}\text { Time }^{\mathrm{c}} \\
(\mathrm{min})\end{array}$ & $\begin{array}{c}\text { Yield }^{\mathrm{d}} \\
(\%)\end{array}$ \\
\hline 1 & 20 & 120 & 25 & 1.8 & DMF & 150 & 92 \\
2 & 20 & 100 & 25 & 1.8 & $\mathrm{DMF}$ & 120 & 25 \\
3 & 20 & 110 & 25 & 1.8 & $\mathrm{DMF}$ & 120 & 45 \\
4 & 20 & 120 & 10 & 0.7 & $\mathrm{DMF}$ & 120 & 65 \\
5 & 20 & 120 & 15 & 1.1 & $\mathrm{DMF}$ & 120 & 80 \\
6 & 20 & 120 & 35 & 2.5 & $\mathrm{DMF}$ & 120 & 90 \\
7 & 20 & reflux & 25 & 1.8 & $\mathrm{H} 2 \mathrm{O}$ & 180 & 0 \\
8 & 20 & 120 & 25 & 1.8 & DMSO & 120 & 75 \\
9 & 10 & 120 & 25 & 3.6 & DMF & 120 & 80 \\
10 & 30 & 120 & 25 & 1.2 & DMF & 180 & 55 \\
\hline
\end{tabular}

a Reaction conditions: benzonitrile ( $1 \mathrm{mmol}), \mathrm{NaN}_{3}(1.5 \mathrm{mmol})$.

${ }^{\mathrm{b}}$ Copper content of the catalyst has measured by atomic absorption instrumentation.

${ }^{\mathrm{c}}$ Reaction time is based on the consumption of benzonitrile monitored by TLC.

${ }^{\mathrm{d}}$ Isolated yield.

$n$-butylamine in acetonitrile. As shown in figure 6, 20-CM displays higher strength than the other samples.

Mesostructure of the 20-CM sample was further studied by TEM, as shown in figure 7. Porosity of the sample is clear and size of the pores is observed in range of 2-3 $\mathrm{nm}$. No copper oxide nanoparticles were observed in the TEM image, suggesting that copper is completely dispersed in MCM-41 framework and also due to the incorporation of $\mathrm{Cu}$ into the MCM-41 framework, partially disordered mesoporus structure is observed.

Table 2. Synthesis of 5-substituted $1 H$-tetrazole derivatives. ${ }^{a}$

\begin{tabular}{|c|c|c|c|c|c|c|}
\hline \multirow[b]{2}{*}{ Entry } & \multirow[b]{2}{*}{ Substrate (1) } & \multirow[b]{2}{*}{ Product (2) } & \multirow[b]{2}{*}{$\operatorname{Time}^{\mathrm{b}}(\mathrm{min})$} & \multirow[b]{2}{*}{ Yield $^{\mathrm{c}}(\%)$} & \multicolumn{2}{|c|}{ M.p. $\left({ }^{\circ} \mathrm{C}\right)$} \\
\hline & & & & & Found & Reported $^{\text {ref }}$ \\
\hline $\mathrm{a}$ & & & 120 & 92 & 218-219 & $215-216^{28}$ \\
\hline $\mathrm{b}$ & & & 150 & 91 & $231-232$ & $231-233^{23}$ \\
\hline $\mathrm{c}$ & & & 90 & 89 & $252-253$ & $252-254^{29}$ \\
\hline d & & & 120 & 90 & $137-139$ & $138-139^{23}$ \\
\hline e & & & 30 & 85 & $145-146$ & $145-146^{30}$ \\
\hline f & & & 30 & 80 & $218-220$ & $218-220^{11}$ \\
\hline $\mathrm{g}$ & & & 30 & 93 & $258-260$ & $258-260^{13}$ \\
\hline $\mathrm{h}$ & & & 45 & 75 & $215-216$ & $214-216^{5}$ \\
\hline $\mathrm{i}$ & & & 180 & 84 & 205-206 & $205-206^{31}$ \\
\hline $\mathrm{j}$ & & & 180 & 89 & $212-214$ & $211^{28}$ \\
\hline
\end{tabular}

${ }^{a}$ Reaction conditions: nitrile $(1 \mathrm{mmol}), \mathrm{NaN}_{3}(1.5 \mathrm{mmol}), 20-\mathrm{CM}(25 \mathrm{mg}), \mathrm{DMF}(3 \mathrm{~mL})$ and temperature $\left(120^{\circ} \mathrm{C}\right)$.

${ }^{b}$ Reaction time is based on the consumption of nitrile monitored by TLC.

c Isolated yield. 
<smiles>[R]c1ccc(C#N)cc1</smiles>

(1)

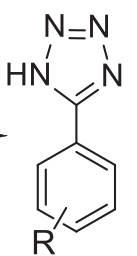

(2)
Scheme 3. Synthesis of tetrazole derivatives using $\mathrm{Cu}$ MCM-41.

The catalytic activities of $\mathrm{Cu}-\mathrm{MCM}-41$ samples were investigated in the synthesis of 5-substituted $1 \mathrm{H}$-tetrazoles by the reaction of various nitriles and sodium azide. To optimize the reaction conditions, initially, the reaction of benzonitrile and sodium azide was selected as the model reaction (scheme 2).

The reaction was optimized for various parameters such as temperature, solvent and catalyst loading. To investigate the effect of temperature, the reaction was performed at 100,110 and $120^{\circ} \mathrm{C}$ and the best result was obtained at $120^{\circ} \mathrm{C}$ (table 1 , entries $1-3$ ). To optimize the catalyst amount, the model reaction was performed in the presence of various amounts of the catalyst and according to the obtained results $25 \mathrm{mg}$ of the catalyst was chosen as the best catalyst amount (table 1, entries 4-6). The effect of solvent was also investigated by performing the model reaction in the presence of 25 mg catalyst in various solvents (table 1 , entries 7,8 ). Among them, DMF was found to be the best solvent in terms of the time and yield of desired product.

Table 3. Reusability test of the catalyst in the model reaction $^{\mathrm{a}}$.

\begin{tabular}{lcccc}
\hline Entry & Fresh & Cycle 1 & Cycle 2 & Cycle 3 \\
\hline Yield (\%) & 92 & 87 & 85 & 85 \\
Time (min) & 120 & 120 & 120 & 120 \\
\hline
\end{tabular}

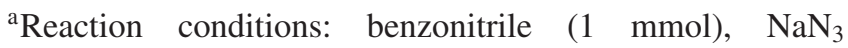
(1.5 mmol), 20-CM (25 mg), DMF (3 mL) and temperature $\left(120^{\circ} \mathrm{C}\right)$.
To investigate the effect of $\mathrm{Cu}$ loading on the catalytic activity of $\mathrm{Cu}-\mathrm{MCM}-41$, the model reaction was performed in the presence of 10-CM and 30-CM samples in the optimized conditions and results show that these catalysts have considerable lower catalytic activity relative to $20-\mathrm{CM}$ (table 1 , entries 9,10 ).

Thereafter, the above optimized reaction conditions were explored for the synthesis of 5-substituted $1 \mathrm{H}$ tetrazole derivatives and the results are summarized in table 2. As exemplified in table 2, this protocol is rather general for a wide variety of electron-rich as well as electron-deficient aromatic nitriles (scheme 3).

The most important benefit of the applied catalyst is its reusability. Thus, the recovery and reusability of the catalyst were investigated in the model reaction under the optimized reaction conditions. The catalyst was separated from the reaction mixture by centrifugation and reused three times with moderate loss of the catalytic activity (table 3 ).

We perform a comparative study of the reactivity of $\mathrm{Cu}-\mathrm{MCM}-41$ with other reported heterogeneous catalytic systems. Table 4 presents other reported methods for the synthesis of 5 -substituted $1 \mathrm{H}$-tetrazoles via $[3+2]$ cycloaddition reaction of nitriles with sodium azide. Reported results in table 4 are related to the standard reaction of benzonitrile and sodium azide at different catalyst loadings. Results show that our method is comparable with other catalytic systems in term of yield and reaction time. In addition to this, moderate reaction temperature, easy work-up and using a reusable catalyst are other benefits of this method.

\section{Conclusion}

In conclusion, we introduced an efficient catalyst for the synthesis of 5-substituted $1 H$-tetrazoles from nitriles and sodium azide with excellent to good yields and low reaction times. Mesoporous copper modified catalyst was prepared at room temperature without using hydrothermal condition with various $\mathrm{Si} / \mathrm{Cu}$ molar ratios. The catalyst was characterized by XRD, FTIR, SEM and TEM techniques. Results show that the $\mathrm{Cu}-\mathrm{MCM}-1$ with $\mathrm{Si} / \mathrm{Cu}$ molar ratio of 20 has the

Table 4. Comparsion of our work with other heterogeneous catalysts.

\begin{tabular}{lccccc}
\hline Entry & Catalyst & Condition & Temp. $\left({ }^{\circ} \mathrm{C}\right)$ & Time $(\mathrm{h})$ & yield\% \\
\hline 1 & Cu-MCM-41 & DMF & 120 & 2 & 92 [this work] \\
2 & Nano-ZnO & DMF & $120-130$ & 14 & $72^{12}$ \\
3 & Amberlyst-15 $^{2}$ & DMSO & 85 & 12 & $92^{32}$ \\
4 & CuFe $_{2} \mathrm{O}_{4}$ & DMF & 120 & 12 & $82^{23}$ \\
5 & $\mathrm{CoY} z e o l i t e^{33}$ & DMF & 120 & 14 & $90^{33}$ \\
\hline
\end{tabular}


best catalytic activity. The simple experimental procedure, easy workup, ease of the catalyst recovery and reusability make this method attractive for the synthesis of tetrazoles.

\section{References}

1. Holland G F and Pereira J N 1967 J. Med. Chem. 10149

2. Xue H, Gao Y, Twamley B and Shreeve J n M 2004 Chem. Mater. 17191

3. Herr R J 2002 Biorg. Med. Chem. 103379

4. Gutmann B, Roduit J P, Roberge D and Kappe C O 2010 Angew. Chem. Int. Ed. Engl. 497101

5. Chermahini A N, Teimouri A, Momenbeik F, Zarei A, Dalirnasab Z, Ghaedi A and Roosta M $2010 \mathrm{~J}$. Heterocycl. Chem. 47913

6. Patil D, Deshmukh M and Dalal D 2012 J. Iranian Chem. Soc. 9799

7. Amantini D, Beleggia R, Fringuelli F, Pizzo F and Vaccaro L 2004 J. Org. Chem. 692896

8. Herbst R M and Wilson K R 1957 J. Org. Chem. 221142

9. Kumar A, Narayanan R and Shechter H 1996 J. Org. Chem. 614462

10. Matthews D P, Green J E and Shuker A J 1999 J. Comb. Chem. 219

11. Jin T, Kitahara F, Kamijo S and Yamamoto Y 2008 Tetrahedron Lett. 492824

12. Lakshmi Kantam M, Kumar K B S and Sridhar C 2005 Adv. Synth. Catal. 3471212

13. Chermahini A N, Teimouri A and Moaddeli A 2011 Heteroat. Chem. 22168

14. Abdollahi-Alibeik M and Pouriayevali M 2012 Catal. Commun. 2213

15. Sivaguru P, Parameswaran K, Kiruthiga M, Vadivel P and Lalitha A 2014 J. Iranian. Chem. Soc. 1295

16. Farzaneh F, Zamanifar E and Williams C D 2004 J. Mol. Catal. A: Chem. 218203
17. Choi J-S, Yoon S-S, Jang S-H and Ahn W-S 2006 Catal. Today 111280

18. Wang L, Kong A, Chen B, Ding H, Shan Y and He M 2005 J. Mol. Catal. A: Chem. 230 143

19. Vetrivel S and Pandurangan A 2006 J. Mol. Catal. A: Chem. 246223

20. Cortés Corberán V, Jia M J, El-Haskouri J, Valenzuela R X, Beltrán-Porter D and Amorós P 2004 Catal. Today 91-92 127

21. Szegedi A, Popova M, Mavrodinova V, UrbaÌ n M, Kiricsi I and Minchev C 2007 Microporous Mesoporous Mater. 99149

22. Higashimoto $\mathrm{S}, \mathrm{Hu} \mathrm{Y}$, Tsumura R, Iino K, Matsuoka M, Yamashita H, Shul Y G, Che M and Anpo M 2005 J. Catal. 235272

23. Sreedhar B, Kumar A S and Yada D 2011 Tetrahedron Lett. 523565

24. Sobczak I, Ziolek M, Renn M, Decyk P, Nowak I, Daturi M and Lavalley J-C 2004 Microporous Mesoporous Mater. $\mathbf{7 4} 23$

25. Liu C-C and Teng H 2005 Appl. Catal. B 5869

26. Abdollahi-Alibeik M and Rezaeipoor-Anari A 2014 Cat. Sci. Tech. 41151

27. Pizzio L R, Vázquez P G, Cáceres C V and Blanco M N 2003 Appl. Catal. A 256125

28. Demko Z P and Sharpless K B 2001 J. Org. Chem. 66 7945

29. Cantillo D, Gutmann B and Kappe C O 2012 J. Org. Chem. 7710882

30. Jursic B S and Leblanc B W 1998 J. Heterocycl. Chem. 35405

31. Elpern B and Nachod F C $1950 \mathrm{~J}$. Am. Chem. Soc. 72 3379

32. Shelkar R, Singh A and Nagarkar J 2013 Tetrahedron Lett. 54106

33. Rama V, Kanagaraj K and Pitchumani K 2011 J. Org. Chem. $\mathbf{7 6} 9090$ 